because the Indonesian Army had guns and friends, and the men in offices thought that Papua's bird mouth would never open and speak for itself. (p. 22)

Etherington's book highlights the human rights violations occurring in a country where no media spotlight is allowed and contributes to public consciousness-raising about West Papua. Ultimately, The Earth Cries Out documents a nation crying out to be heard, crying out for its freedom. The Earth Cries Out implores for the silence about West Papua to come to an end and for journalists to play their role in making this happen.-Kendall Hutt is Pacific Media Watch freedom project editor.

\section{Right-wing rhetoric makes the unpalatable normal}

The Politics of Fear. What right-wing populist discourses mean, by Ruth Wodak. London: Sage, 2015. 256 pages. ISBN 978-1- 4462-470-0-6

AS WE observe political events unfolding in the United States, the Brexit vote in the UK, the discourse around Korea, the French elections and the rhetoric of European nations, Wodak's book provides a timely insight into the discourse of right-wing populism and why it is successful.

In each of the eight chapters, Wodak provides campaign materials, images, online data, television interviews and news stories. A total of 15 vignettes/political snapshots are used to help the reader decode right-wing populist messages. Un-

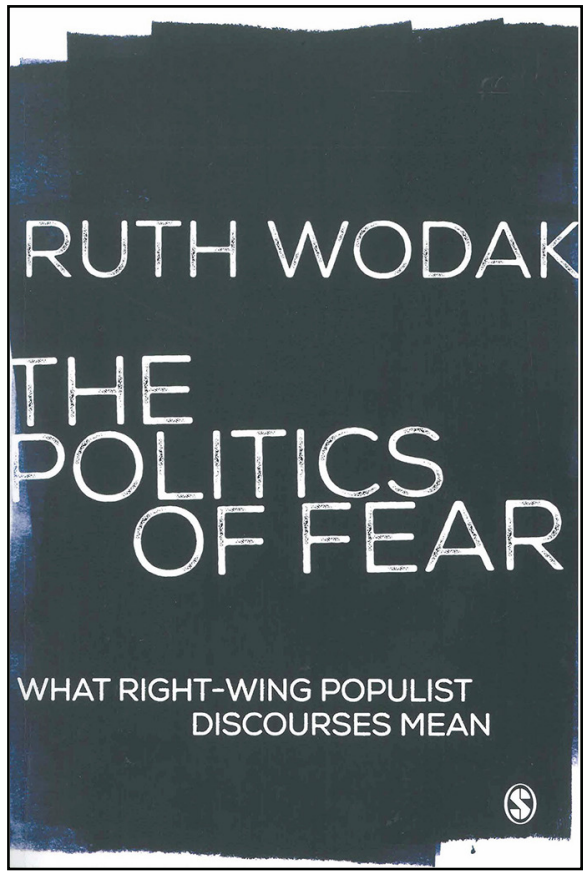

derstanding the range of rhetorical devices being used to normalise nationalistic, racist and anti-Semitic discourses, explains why and how these political actors and discourses have constructed their appeal and as a result are becoming mainstream in the public sphere.

Identity construction and the reshaping of nationalism through immigration policies are covered, along with an historical tracking of political actors and parties and their discourse and strategies in the early chapters. The reader is helped to understand how these political actors set the agenda and frame media debates today. Wodak provides the reader with an in-depth deconstruction of how individual and collective identities are used by rightwing populist groups to justify their views about who should be considered 
as suitable in-members in order to participate in the social, cultural and political life of their countries and who should not.

The analysis examines the "front stage' where the public/voters are present and the 'back stage' where politics is done. Political actors are seen as performers on the front stage conveying empathy, anger and discontent in relational terms using phrases and tunes that capture the ideas that 'we' are against the elites, against those up there - the 'them' and 'us' rhetoric being used to convince voters that they, the political actors, are like them and thus understand the 'fear' of the ordinary person/of us. The press coverage thus gained of their messages helps further their control of the political and media agenda.

The final chapter concludes with a message addressed to the media, public opinion and political actors to dismantle these politically manipulative dynamics. Wodak provides a way forward to change the current discourses of fear through strategies such as the use of discourses that are inclusive, the use of 'we' terms and not the divisive 'us vs them', the use of language that promotes values of well-being, dignity, equality, diversity and solidarity.

Wodak is a prolific researcher and writer in the field of critical discourse analysis with much of her work focused on the study of political extremism. This book is an accessible read, encompassing her extensive knowledge of what has been published in the area with her examination of the politics of fear.
Her writing is targeted not just at academia but to those outside this sphere. As Wodak states in her preface: 'I have made a point of employing a more popular comprehensible style of writing while still doing justice to the requirements of systematic linguistic analysis' (p. xii). Wodak also provides informative and clear tables of linguistic strategies, including a useful explanatory table on fallacy in chapter three.

The book is useful for students interested in linguistics and political discourse and for media and communication professionals because it helps understand the range of rhetorical devices used by political actors to reshape and communicate their content, the logical fallacies used in political discourses and what needs to be done to challenge the language and the discourses.-LYNNE TRENWITH is an Auckland-based communications academic and consultant.

\section{Questions of great intricacy opened up to non-Arabic audience}

Media and Political Contestation in the Contemporary Arab World, edited by Lena Jayyusi and Anne Sofie Roald. Basingstoke/ New York: Palgrave MacMillan 2016. 327 pages. ISBN 978-1-137-5252-2-2.

\section{MEDIA and Political Contestation} in the Contemporary Arab World explores the extremely complicated reality of the Arab media and its place in the political and cultural debates that are rarely recognised or understood in the west. In the Middle East, media of 